\title{
Short communication: Production response of lactating dairy cows to brachytic forage sorghum silage compared with corn silage from first or second harvest
}

\author{
J. K. Bernard ${ }^{1}$ and S. Tao \\ Department of Animal and Dairy Science, University of Georgia, Tifton 31793
}

\begin{abstract}
A completely randomized lactation trial was conducted to compare the production response of lactating Holstein cows to diets based on corn or forage sorghum silage harvested from 2 crops. Corn was planted in March and harvested in July (corn silage-summer; CSS) and a second corn crop was planted in July and harvested in November (corn silage-fall; CSF). A brachytic dwarf brown midrib forage sorghum was planted in April, harvested in July (forage sorghumsummer; FSS), fertilized, and harvested a second time in November (forage sorghum-fall; FSF). All forage was ensiled in plastic bags and stored until the production trial began. Silages contained (dry matter basis) 8.0, 8.5, 9.0, and $9.5 \%$ crude protein; 39.0, 38.3, 54.2, and $55.1 \%$ neutral detergent fiber; and 3.6, 2.8. 7.7, and $7.8 \%$ acid detergent lignin, for CSS, CSF, FSS, and FSF, respectively. Forty-eight mid-lactation Holstein cows $(153.5 \pm 37.2 \mathrm{~d}$ in milk, $35.7 \pm 6.2 \mathrm{~kg} / \mathrm{d}$ of milk, $3.2 \pm 0.6 \%$ fat, $611.8 \pm 67.0 \mathrm{~kg}$ of body weight, and 2.96 \pm 0.09 body condition score) were assigned randomly to 1 of the 4 diets differing in forage source. Cows were individually fed experimental diets once daily behind Calan doors for 5 wk. Diets were formulated to contain $38.7 \%$ of the experimental forages and balanced to provide equal concentrations of protein, fiber, and energy. No differences were observed in dry matter intake and yields of milk and components, but milk fat percentage was lower for CSS and CSF compared with FSS and FSF, being 3.20, 2.91, 3.42, and 3.53\%, respectively. Milk lactose percentage was lower for CSS compared with CSF but was not different from FSS or FSF. Concentrations of milk urea nitrogen were lower for CSS and CSF compared with FSS and FSF $(10.6,13.4$, 14.9, and $15.3 \mathrm{mg} / \mathrm{dL}$, respectively). No differences were observed in body weight or body condition score change during the trial. Results of this trial suggest that silage produced from brachytic forage sorghum, as either the
\end{abstract}

Received April 16, 2015.

Accepted August 17, 2015.

${ }^{1}$ Corresponding author: jbernard@uga.edu first or the ratoon crop, can support similar intake and performance as diets based on corn silage.

Key words: corn silage, forage sorghum, milk yield, milk composition

\section{Short Communication}

Forage sorghum (FS) is grown in many areas of the southern United States where irrigation is not available or limited because of its drought tolerance and lower water requirement compared with corn (ContrerasGovea et al., 2010). Compared with corn silage (CS), forage sorghum silage has lower starch and higher fiber concentrations, resulting in lower energy concentrations compared with corn (NRC, 2001). When lactating dairy cows were fed diets based on normal FS, milk yield was not different from that of cows fed tropical CS (Nichols et al., 1998) but was lower than of cows fed temperate CS (Aydin et al., 1999). Varieties of FS with the brown midrib 6 gene (BMR) produce forage that has lower lignin concentrations that support higher NDF digestibility (Contreras-Govea et al., 2010). Diets based on BMR FS have been reported to support FCM yields similar to that of cows fed diets based on CS (Grant et al., 1995; Aydin et al., 1999; Oliver et al., 2004).

Varieties with the brachytic dwarf gene are shorter (approximately $1.8 \mathrm{~m}$ in height versus $\geq 3.6 \mathrm{~m}$ ) than normal FS and are more resistance to lodging. Yosef et al. (2009) reported similar forage DM yield and fiber digestibility for dwarf compared with a normal variety of FS. Brachytic dwarf varieties and the BMR gene are currently being used in forage production system by dairy producers, but data are limited as to the feeding value of these hybrids.

In the southern United States, a second crop of forage can be harvested without replanting when FS is planted in spring and allowed to ratoon. Yosef et al. (2009) reported higher NDF and lignin concentrations in the ratoon harvest of FS, but concentrations of other nutrients were similar. Those researchers did not observe any difference in nutrient digestibility when first or ratoon FS was fed to sheep (Yosef et al., 2009). Data are lacking on the production response of lactat- 
ing dairy cows or growing animals fed FS harvested from both the first and ratoon crops. The objective of this trial was to evaluate the effects of diets based on source of whole-plant silage (corn or forage sorghum) harvested in either summer or fall on intake and performance when fed to lactating dairy cows.

All forages were grown on the Animal and Dairy Science Department farm unit located on the University of Georgia Tifton Campus on a Tifton sandy loam soil. Temperate corn (Pioneer P1404, DuPont Pioneer, Johnston, IA) was planted on March 22, 2012, at a seeding rate of approximately 79,070 seeds/ha. Forage was harvested on July 24, 2012, and ensiled in a plastic bag until beginning of a production trial. The second crop (DeKalb 67-88, Monsanto Company, St. Louis, MO) was planted at the same seeding rate on July 31, 2012 , and was managed as outlined for the first crop. Corn was harvested on November 8, 2012, and ensiled in a plastic bag.

A brachytic dwarf BMR FS variety (Alta 7401, Alta Seeds, Amarillo, TX) was planted at a seeding rate of approximately 276,000 seeds/ha $(7.85 \mathrm{~kg} / \mathrm{ha})$ on April 12, 2012. Forage was harvested on July 25, 2012, when the grain had reached the soft dough stage of maturity, and ensiled in a plastic bag until the beginning of a production trial. The crop was fertilized and allowed to regrow and produce a second crop. The forage was harvested on November 9, 2012, at the soft dough stage of maturity and ensiled in a plastic bag.

For both CS and FS, $44.7 \mathrm{~kg} / \mathrm{ha} \mathrm{N}, 44.7 \mathrm{~kg} / \mathrm{ha} \mathrm{P}_{2} \mathrm{O}_{5}$, and $93.4 \mathrm{~kg} / \mathrm{ha} \mathrm{K}_{2} \mathrm{O}$ were applied before planting and top dressed with $154 \mathrm{~kg} /$ ha $\mathrm{N}$. The same fertilization program was used for the second crop of corn. The ratoon crop of forage sorghum received $73 \mathrm{~kg} / \mathrm{ha} \mathrm{N}, 18.3$ $\mathrm{kg} / \mathrm{d} \mathrm{P}_{2} \mathrm{O}_{5}$, and $36.6 \mathrm{~kg} / \mathrm{ha} \mathrm{K}_{2} \mathrm{O}$ and was top dressed with $154 \mathrm{~kg} / \mathrm{ha} \mathrm{N}$. Herbicides were applied according to University of Georgia recommendations, and crops were irrigated as needed to maintain soil moisture.

Forty-eight lactating Holstein cows (16 primiparous and 32 multiparous, average 2.9 lactations) averaging $153.5 \pm 37.2 \mathrm{DIM}, 35.7 \pm 6.2 \mathrm{~kg} / \mathrm{d}$ of milk, $3.2 \pm 0.6 \%$ fat, $611.8 \pm 67.0 \mathrm{~kg}$ of $\mathrm{BW}$, and $2.96 \pm 0.09 \mathrm{BCS}$ were used in a 7-wk randomized design trial. Cows were trained to eat behind Calan doors (American Calan, Northwood, NH) before beginning the trial. All cows were fed a basal diet based on CS harvested in summer for $2 \mathrm{wk}$ and data collected for use as a covariate in the statistical analysis. At the end of the preliminary period, cows were assigned, within parity, to 1 of 4 treatments by ECM for the following 5 wk. Treatments include 4 forage sources: (1) summer CS (CSS), (2) fall CS (CSF), (3) summer FS (FSS), or (4) regrowth fall FS (FSF). Diets (Table 1) were formulated to provide equal concentrations of protein, NDF, and energy based
Table 1. Ingredient composition of experimental diets (\% of DM)

\begin{tabular}{|c|c|c|}
\hline Ingredient & $\begin{array}{l}\text { Corn } \\
\text { silage }\end{array}$ & $\begin{array}{c}\text { Forage } \\
\text { sorghum }\end{array}$ \\
\hline Corn silage $^{1}$ & 38.71 & \\
\hline Forage sorghum $^{2}$ & & 38.71 \\
\hline Oat baleage & 6.88 & 3.44 \\
\hline Brewers grains, wet & 11.61 & 11.61 \\
\hline Whole cottonseed & 5.59 & \\
\hline Ground corn & 19.96 & 26.41 \\
\hline Soybean hulls & 2.06 & 2.06 \\
\hline Soybean meal & 3.48 & 6.06 \\
\hline Megalac $^{3}$ & 1.72 & 1.72 \\
\hline Amino Plus ${ }^{4}$ & 2.84 & 2.84 \\
\hline Prolak ${ }^{5}$ & 3.18 & 3.18 \\
\hline Urea & 0.26 & 0.26 \\
\hline Salt & 0.26 & 0.26 \\
\hline Calcium carbonate & 0.86 & 0.86 \\
\hline Potassium carbonate & 0.60 & 0.60 \\
\hline Magnesium oxide & 0.26 & 0.26 \\
\hline Sodium bicarbonate & 0.77 & 0.77 \\
\hline Availa- $4^{6}$ & 0.03 & 0.03 \\
\hline Potassium magnesium sulfate & 0.17 & 0.17 \\
\hline Omigen- $\mathrm{AF}^{7}$ & 0.22 & 0.22 \\
\hline Monensin, ${ }^{8} 3 \mathrm{~g} / 454 \mathrm{~g}$ & 0.38 & 0.38 \\
\hline Vitamin E, 20,000 IU/454 g & 0.02 & 0.02 \\
\hline Trace-mineral-vitamin premix ${ }^{9}$ & 0.14 & 0.14 \\
\hline
\end{tabular}

${ }^{1}$ Corn silage was provided from silage harvested during the summer or fall.

${ }^{2}$ Forage sorghum was provided from silage harvested during the summer or fall.

${ }^{3}$ Calcium salts of long-chain fatty acids (Arm Hammer Animal Nutrition, Church \& Dwight Co. Inc., Princeton, NY).

${ }^{4}$ Ruminally protected soybean meal (Ag Processing Inc., Omaha, NE). ${ }^{5}$ Marine and animal rumen undegradable protein supplement (H. J. Baker \& Bros. Inc., Westport, CT).

${ }^{6}$ Organic zinc, manganese, copper, and cobalt (Zinpro Corp., Eden Prairie, MN).

${ }^{7}$ Immune stimulant (Prince Agri Products Inc., Quincy, IL).

${ }^{8}$ Rumensin (Elanco Animal Health, Indianapolis, IN).

${ }^{9}$ Mineral-vitamin premix contained (DM basis): $26.1 \% \mathrm{Ca} ; 0.38 \% \mathrm{Mg}$; $1.76 \% \mathrm{~S} ; 144 \mathrm{mg} / \mathrm{kg}$ of $\mathrm{Co} ; 9,523 \mathrm{mg} / \mathrm{kg}$ of $\mathrm{Cu} ; 1,465 \mathrm{mg} / \mathrm{kg}$ of $\mathrm{Fe}$; $842 \mathrm{mg} / \mathrm{kg}$ of I; $28,617 \mathrm{mg} / \mathrm{kg}$ of Mn; $220 \mathrm{mg} / \mathrm{kg}$ of Se; $25,343 \mathrm{mg} / \mathrm{kg}$ of $\mathrm{Zn} ; 4,210,830 \mathrm{IU} / \mathrm{kg}$ of vitamin A; 1,684,330 IU $/ \mathrm{kg}$ of vitamin D; $21,045 \mathrm{IU} / \mathrm{kg}$ of vitamin E.

on preliminary forage analysis and fed as a TMR once daily in amounts to provide a minimum of $5 \%$ orts.

The amount of feed offered and refused was recorded daily. Samples of dietary ingredients, experimental rations, and orts were collected for DM analysis 3 times each week. Rations were adjusted as necessary to account for changes in the DM content of individual ingredients. Individual samples were composited by week and ground to pass through a $1-\mathrm{mm}$ screen using a Wiley mill (Thomas Scientific, Swedesboro, NJ). Forage samples were analyzed for concentrations of DM, ash (AOAC International, 2000), CP (Leco FP528 Nitrogen Analyzer, St. Joseph, MO), ADF (AOAC International, 2000), NDF adjusted for ash (Van Soest et al., 1991), ADL adjusted for ash, 30-h NDF digestibility (Goering and Van Soest, 1970), sugar (Dubois 
et al., 1956), starch (Hall, 2009), ether extract, and minerals (AOAC International, 2000). Samples of experimental diets were analyzed for DM, ash, $\mathrm{CP}, \mathrm{ADF}$ (AOAC International, 2000), and NDF adjusted for ash (Van Soest et al., 1991). Concentrations of soluble protein, $\mathrm{NFC}$, and $\mathrm{NE}_{\mathrm{L}}$ were calculated using forage chemical analysis and database values in Cornell Net Carbohydrate and Protein System, version 6.1 (Tedeschi et al., 2008; Tylutki et al., 2008). Fermentation end product concentrations of the experimental silages were determined using the filtrate of a 25 -g wet sample blended with $200 \mathrm{~mL}$ of distilled water. Sample $\mathrm{pH}$ and concentrations of ammonia- $\mathrm{N}$, and lactic, acetic, propionic, butyric, and isobutyric acids were determined as described by Barlow et al. (2012).

Cows were milked 3 times daily at 0700, 1500, and 2300 h. Daily milk yields for each cow were recorded electronically (Alpro, DeLaval, Kansas City, MO). Milk samples were collected from 3 consecutive milkings once a week for analysis of milk fat, protein, lactose, SNF, and MUN concentrations by infrared spectrophotometric analysis with a Foss 4000 instrument (Foss North America, Eden Prairie, MN; Dairy One Cooperative, Ithaca, NY).

Individual BW was recorded on 3 consecutive days following the $0700 \mathrm{~h}$ milking at the end of the pretrial period and at the end of the experimental period. To minimize variation, BW was recorded immediately after milking before allowing access to feed or water. Body condition scores were assigned by 2 individuals during the last week of the preliminary period and wk 5 of the experimental period as described by Wildman et al. (1982).

Data from wk 3 through 5 of the production trial were subjected to analysis of covariance using the PROC MIXED procedure of SAS (SAS Institute, 2008). The model included effects of covariate, parity, treatment, week, and the interaction of treatment and week. Data collected from the 2-wk preliminary period were used as a covariate and was significant for all variables. Cow within treatment was included as a random effect and week was included as a repeated measure. The firstorder autoregressive covariance structure was used according to Littell et al. (1998). Significance was declared when $P \leq 0.05$. When significance was detected, the Tukey test was used for mean separation.

The chemical composition of the experimental silages from summer and fall harvests is presented in Table 2. Harvest of CSS was delayed by rain and mechanical breakdown, resulting in higher $\mathrm{DM}$ and $\mathrm{pH}$ and lower total VFA concentrations than desired. In general, forage sorghum silages had higher concentrations of $\mathrm{NDF}, \mathrm{ADF}$, and lignin than corn silages, whereas corn silages had higher concentrations of starch and NFC, and NDF digestibility. There were minor differences in the chemical analysis of summer and fall silage within forage type, except that starch digestibility was higher for forages harvested in the fall compared with those harvested in the summer.

The CP content of the experimental diets was similar (Table 3). Concentrations of NDF and ADF were slightly higher and NFC was slightly lower for diets based on FSS and FSF compared with those based on CSS and CSF. Calculated dietary $\mathrm{NE}_{\mathrm{L}}$ concentrations, based on chemical analysis of forages, were higher for CSF compared with CSS, FSS, and FSF.

No differences were observed in DMI (Table 4) but an interaction of treatment and week $(P<0.001)$ was observed for DMI (Figure 1) because the DMI of cows fed FSS increased, whereas DMI of cows fed CSS decreased from wk 3 to 5 . The reason for the decrease in DMI for CSS is not readily apparent. All silages were stable and did not change during the trial (Table 2). Previous research comparing single harvest BMR FS with CS has not reported any differences in DMI (Aydin et al., 1999; Oliver et al., 2004; Miron et al., 2007). However, Grant et al. (1995) reported higher DMI for cows fed diets based on BMR FS compared with those fed diets based on CS. The dietary NDF contents of both FSand CS-based diets were similar in that trial (Grant et al., 1995). Shaver (2010) reported higher DMI when cows were fed BMR compared with normal CS. The increase in DMI with BMR CS has been attributed to reduced physical fill because of the higher NDF digestibility of BMR CS (Oba and Allen, 1999). Although not significantly different, DMI of cows fed BMR compared with normal FS has been numerically higher (Grant et al., 1995; Aydin et al., 1999), suggesting that the higher NDF digestibility would support reduced physical fill allowing improved DMI.

No differences were observed in yield of milk and components, or percentage of milk protein or SNF. No differences in milk yield have been reported for cows fed BMR FS- or CS-based diets (Grant et al., 1995; Oliver et al., 2004; Miron et al., 2007). In contrast, Aydin et al. (1999) reported lower milk yield of cows fed diets based on BMR FS compared with CS.

Milk fat percentage was higher $(P=0.02)$ for cows fed FSS and FSF compared with CSS and CSF. Previous research has reported higher milk fat percentage for diets based on BMR FS compared with CS (Miron et al., 2007) although others have not observed any difference (Grant et al., 1995; Aydin et al., 1999; Oliver et al., 2004). No difference was observed in milk protein percentage, but an interaction of treatment and week $(P=0.02)$ was observed because concentrations were similar during wk 3 and 4 but increased during wk 5 for CSS and CSF compared with FSS and FSF (Figure 
Table 2. Chemical composition (\% of DM unless otherwise noted; mean \pm SD) of corn (CS) and forage sorghum (FS) silages harvested in the summer (S) or fall (F)

\begin{tabular}{|c|c|c|c|c|}
\hline Item & CSS & $\mathrm{CSF}$ & FSS & FSF \\
\hline DM, \% & $46.6 \pm 5.1$ & $29.6 \pm 2.0$ & $28.7 \pm 1.7$ & $29.7 \pm 3.4$ \\
\hline $\mathrm{CP}$ & $8.0 \pm 0.5$ & $8.5 \pm 0.3$ & $9.0 \pm 0.6$ & $9.5 \pm 0.6$ \\
\hline NDIP $^{1}$ & $1.49 \pm 0.20$ & $1.10 \pm 0.16$ & $2.51 \pm 0.21$ & $2.24 \pm 0.11$ \\
\hline NDF & $39.0 \pm 1.1$ & $38.3 \pm 1.7$ & $54.2 \pm 1.7$ & $55.1 \pm 2.0$ \\
\hline $\mathrm{ADF}$ & $24.5 \pm 1.2$ & $24.0 \pm 1.3$ & $35.9 \pm 1.2$ & $36.0 \pm 1.8$ \\
\hline Lignin & $3.6 \pm 0.4$ & $2.8 \pm 0.2$ & $7.7 \pm 0.4$ & $7.8 \pm 0.1$ \\
\hline Lignin, $\%$ of NDF & $9.1 \pm 0.8$ & $8.1 \pm 0.6$ & $14.3 \pm 0.7$ & $14.2 \pm 0.7$ \\
\hline NDFd, $30 \mathrm{~h}^{2}$ & $47.1 \pm 2.8$ & $53.0 \pm 1.7$ & $45.8 \pm 3.3$ & $37.4 \pm 2.8$ \\
\hline Ether extract & $3.4 \pm 0.1$ & $3.6 \pm 0.1$ & $3.5 \pm 0.4$ & $3.0 \pm 0.3$ \\
\hline Sugar & $1.4 \pm 0.1$ & $1.0 \pm 0.2$ & $2.2 \pm 0.6$ & $1.6 \pm 0.3$ \\
\hline Starch & $37.2 \pm 0.8$ & $34.0 \pm 1.7$ & $16.8 \pm 0.4$ & $14.1 \pm 2.2$ \\
\hline Starch digestibility, $7 \mathrm{~h}$ & $74.0 \pm 4.6$ & $82.6 \pm 3.4$ & $64.3 \pm 3.8$ & $76.8 \pm 0.5$ \\
\hline $\mathrm{NFC}$ & $48.1 \pm 1.1$ & $47.7 \pm 0.7$ & $31.5 \pm 1.1$ & $29.1 \pm 1.7$ \\
\hline Ash & $3.20 \pm 0.35$ & $4.19 \pm 0.48$ & $5.03 \pm 0.28$ & $4.73 \pm 0.43$ \\
\hline Total VFA & $2.59 \pm 0.50$ & $10.62 \pm 0.78$ & $7.89 \pm 0.80$ & $6.85 \pm 0.67$ \\
\hline Lactic acid & $1.3 \pm 0.3$ & $9.0 \pm 0.9$ & $2.1 \pm 0.1$ & $1.5 \pm 0.3$ \\
\hline Acetic acid & $1.04 \pm 0.34$ & $1.98 \pm 0.50$ & $4.89 \pm 0.75$ & $5.18 \pm 0.34$ \\
\hline Propionic acid & $0.15 \pm 0.03$ & $0.08 \pm 0.06$ & $0.96 \pm 0.45$ & $0.17 \pm 0.10$ \\
\hline Butyric acid & $\mathrm{ND}^{3}$ & ND & ND & ND \\
\hline Isobutyric acid & $0.01 \pm 0.00$ & ND & ND & $0.02 \pm 0.00$ \\
\hline 1,2-Propanediol & $0.69 \pm 0.18$ & $0.39 \pm 0.19$ & $0.27 \pm 0.13$ & $1.41 \pm 0.22$ \\
\hline $\mathrm{pH}$ & $5.11 \pm 1.17$ & $3.95 \pm 0.40$ & $4.12 \pm 0.23$ & $4.45 \pm 0.19$ \\
\hline
\end{tabular}

${ }^{1} \mathrm{NDIP}=$ neutral detergent insoluble protein.

${ }^{2} \mathrm{NDFd}, 30 \mathrm{~h}=30-\mathrm{h}$ NDF digestibility.

${ }^{3} \mathrm{ND}=$ not detected

2). Previous research has reported reduced milk protein (Aydin et al., 1999; Miron et al., 2007) or no differences (Grant et al., 1995; Aydin et al., 1999; Oliver et al., 2004) for FS compared with CS. Differences in these results could be related to difference in ruminal microbial protein synthesis, given the difference in carbohydrate fractions provided by FS compared with CS or dietary protein supplementation.

Milk lactose percentage was lower $(P=0.01)$ for CSS compared with CSF, FSS, and FSF. No differences in milk lactose have been reported previously (Grant et al., 1995; Aydin et al., 1999; Miron et al., 2007). The reason for reduced lactose with CSS could be related to the delay in harvest of CSS, which would have resulted in silage with starch that was less digestible even though forage was subjected to a kernel processor. The trial was conducted during conditions of heat stress, which has been reported to result in less glucose being available for lactose synthesis by the mammary gland (Baumgard et al., 2011) and which might have contributed to the reduction.

No differences were observed in SNF percentage, ECM, or milk production efficiency. However, an interaction of treatment and week $(P<0.0001)$ was observed for milk production efficiency (Figure 3), which decreased in CSF from wk 3 to 4 and in CSS from wk 4 to 5 , whereas milk production efficiency in cows fed FSS and FSF increased from wk 3 to wk 5 . Milk production efficiency has been reported to decrease (Grant et al., 1995; Aydin et al., 1999), improve (Aydin et al., 1999), or be the same (Oliver et al., 2004) for cows fed BMR FS compared with CS. Concentrations of MUN were

Table 3. Chemical analysis (\% of DM unless otherwise noted; mean \pm SD) of experimental diets based on corn (CS) or forage sorghum (FS) silage harvested in the summer (S) or fall (F)

\begin{tabular}{lcccc}
\hline Item & CSS & CSF & FSS & FSF \\
\hline $\mathrm{DM}, \%$ & $47.6 \pm 6.3$ & $39.8 \pm 5.1$ & $38.6 \pm 6.1$ & $39.4 \pm 6.2$ \\
$\mathrm{CP}$ & $16.9 \pm 1.6$ & $16.7 \pm 0.4$ & $16.8 \pm 1.0$ & $17.0 \pm 0.9$ \\
Soluble protein $^{1}$ & 4.6 & 4.9 & 3.9 & 4.7 \\
$\mathrm{RDP}^{1}$ & 10.2 & 10.2 & 11.1 & 10.3 \\
$\mathrm{NDF}$ & $35.1 \pm 1.9$ & $37.9 \pm 1.3$ & $37.5 \pm 1.0$ & $38.9 \pm 2.0$ \\
$\mathrm{ADF}$ & $18.8 \pm 1.2$ & $19.7 \pm 1.7$ & $20.6 \pm 1.7$ & $21.0 \pm 0.7$ \\
Ether extract & $5.6 \pm 0.4$ & $6.0 \pm 0.3$ & $5.7 \pm 0.8$ & $5.2 \pm 0.6$ \\
$\mathrm{NFC}^{1}$ & 38.0 & 37.7 & 35.6 & 35.4 \\
$\mathrm{NE}_{\mathrm{L}}{ }^{1}{ }^{1}$ Mcal/kg of DM & 1.61 & 1.72 & 1.61 & 1.63 \\
\hline
\end{tabular}

${ }^{1}$ Calculated using Cornell Net Carbohydrate and Protein System, version 6.1 (Tedeschi et al., 2008; Tylutki et al., 2008). 


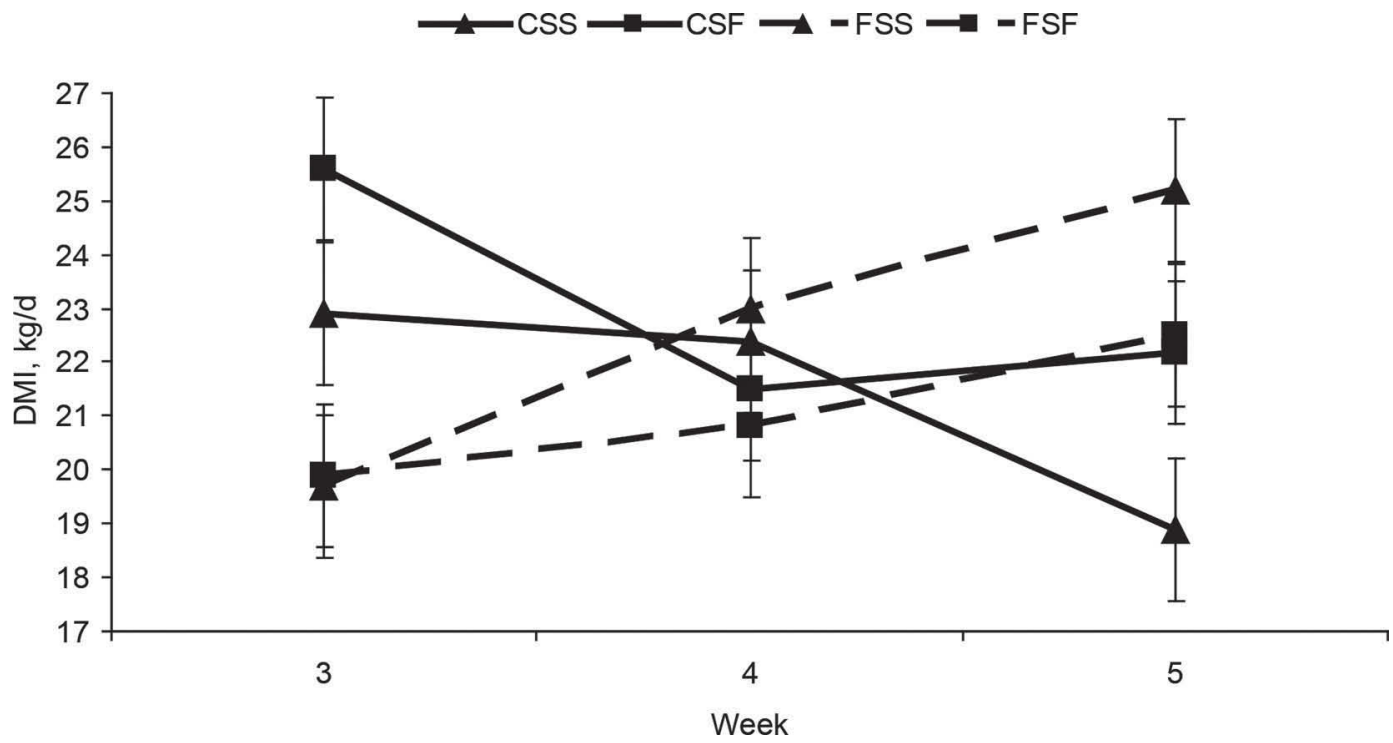

Figure 1. Interaction of treatment and week on DMI $(P<0.0001)$ of cows fed diets based on corn $(\mathrm{CS})$ or forage sorghum (FS) silage harvested in the summer $(\mathrm{S})$ or fall $(\mathrm{F})$.

lower $(P=0.002)$ for CSS and CSF compared with FSS and FSF. An interaction of treatment and week $(P=$ 0.02) was observed for MUN (Figure 4) because MUN concentration for cows fed CSF increased significantly from wk 4 to 5 , whereas no change was observed in MUN concentrations of cows fed CSS, FSS, or FSF. The higher MUN concentrations most likely reflect differences in starch availability between forages and total dietary starch concentrations, which could reduce ruminal $\mathrm{N}$ utilization for microbial protein synthesis. In contrast to our results, Miron et al. (2007) reported lower milk urea concentrations when cows were fed
BMR FS compared with those fed CS. No differences $(P>0.10)$ were observed in change of $\mathrm{BW}$ or BCS, which is consistent with previous reports (Aydin et al., 1999; Miron et al., 2007).

To our knowledge, no data are available regarding the production response of lactating cows to forage produced from a ratoon crop of FS. Yosef et al. (2009) reported greater DMI by sheep fed fall- compared with summer-harvested FS, but no differences were observed in digestibility of NDF. No differences in animal performance were observed in our trial between summer- and fall-harvested forages within forage type, except for

Table 4. Dry matter intake, milk yield, and composition of cows fed diets based on corn (CS) or forage sorghum (FS) silage harvested in the summer (S) or fall (F)

\begin{tabular}{lcccccc}
\hline & \multicolumn{7}{c}{ Treatment } & & \\
\cline { 2 - 5 } Item & CSS & CSF & FSS & FSF & \multirow{2}{*}{ SE } & $P$-value \\
\hline DMI, kg/d & 21.4 & 23.1 & 22.6 & 21.1 & 1.2 & 0.57 \\
Milk, kg/d & 32.2 & 33.4 & 32.9 & 33.5 & 1.5 & 0.92 \\
Fat, \% & $3.20^{\mathrm{a}}$ & $2.91^{\mathrm{a}}$ & $3.42^{\mathrm{b}}$ & $3.53^{\mathrm{b}}$ & 0.14 & 0.02 \\
Fat, kg/d & 1.03 & 0.97 & 1.12 & 1.18 & 0.06 & 0.14 \\
Protein, \% & 2.80 & 2.70 & 2.64 & 2.69 & 0.05 & 0.15 \\
Protein, kg/d & 0.90 & 0.90 & 0.87 & 0.90 & 0.05 & 0.93 \\
Lactose, \% & $4.63^{\mathrm{a}}$ & $4.88^{\mathrm{b}}$ & $4.87^{\mathrm{b}}$ & $4.82^{\mathrm{b}}$ & 0.40 & 0.01 \\
Lactose, kg/d & 1.49 & 1.63 & 1.60 & 1.61 & 0.07 & 0.78 \\
SNF, \% & 8.28 & 8.33 & 8.21 & 8.26 & 0.07 & 0.65 \\
SNF, kg/d & 2.67 & 2.79 & 2.70 & 2.77 & 0.13 & 0.91 \\
ECM, kg/d & 30.8 & 30.4 & 31.9 & 33.1 & 1.4 & 0.64 \\
Efficiency, ECM/DMI & 1.44 & 1.32 & 1.41 & 1.57 & 0.09 & 0.55 \\
MUN, mg/dL & $10.6^{\mathrm{a}}$ & $13.4^{\mathrm{a}}$ & $14.9^{\mathrm{b}}$ & $15.3^{\mathrm{b}}$ & 0.8 & 0.002 \\
BW change, ${ }^{\mathrm{b}} \mathrm{kg}$ & 8.3 & 7.2 & 12.5 & 3.5 & 7.2 & 0.85 \\
BCS change & 0.29 & 0.05 & -0.11 & 0.14 & 0.13 & 0.17 \\
\hline
\end{tabular}

${ }_{\mathrm{a}, \mathrm{b}}$ Means in the same row with unlike superscripts differ $(P<0.05)$.

${ }^{1}$ Change during the 5 -wk trial. 

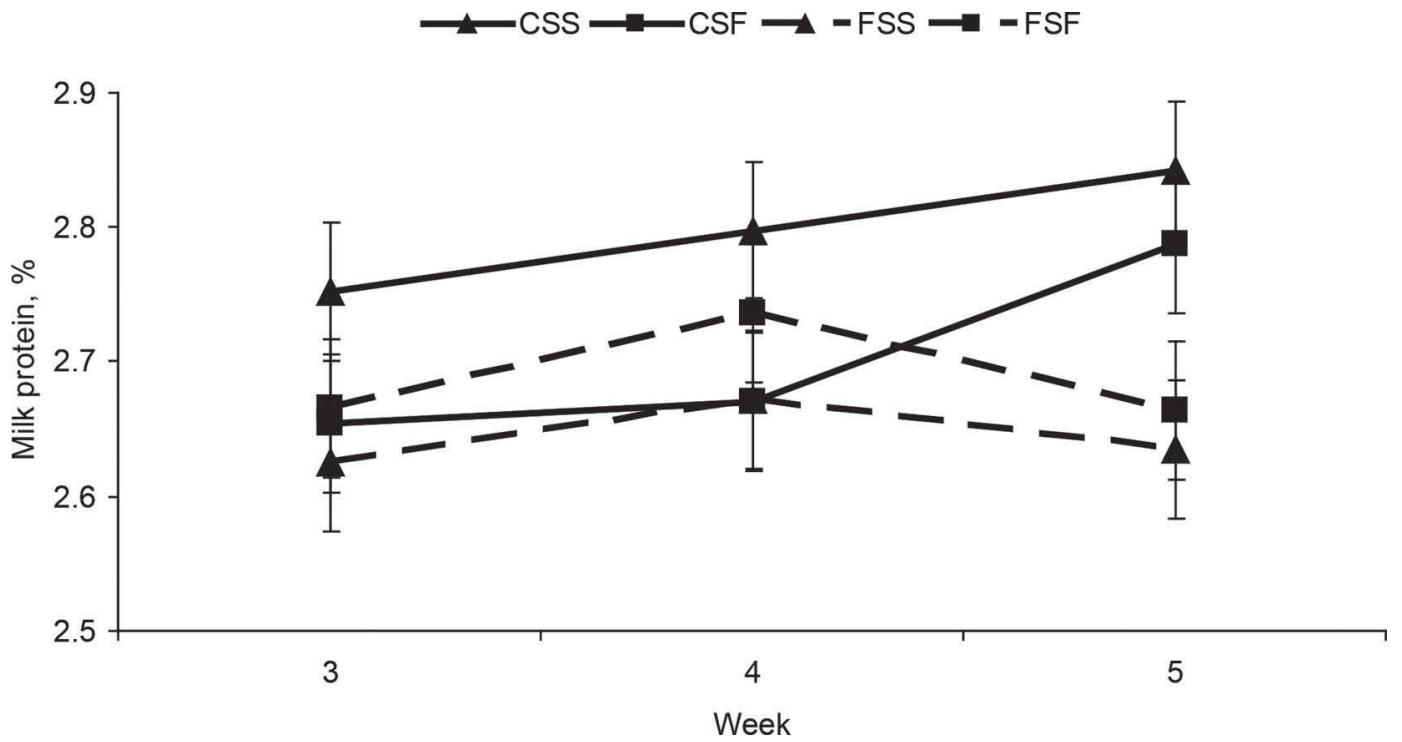

Figure 2. Interaction of treatment and week on milk protein percentage $(P=0.02)$ for cows fed diets based on corn (CS) or forage sorghum (FS) silage harvested in the summer (S) or fall (F).

lactose percentage. Although we detected minor differences in chemical composition, these differences did not seem to alter performance in diets that were balanced for fiber, energy, and protein.

Results of the current trial suggest that silage produced from brachytic dwarf BMR forage sorghum can support similar milk yield and composition as corn silage. The results also suggest that forage harvested from regrowth of brachytic dwarf forage sorghum will support similar milk yields as that produced from the first crop. The higher MUN concentrations observed suggest that ruminal $\mathrm{N}$ fermentation may be altered with forage sorghum compared with corn silage and could be improved either by changes to dietary $\mathrm{N}$ fractions or by carbohydrate supplementation.

\section{ACKNOWLEDGMENTS}

The authors thank the Milk Checkoff funded by Southeast Milk Inc. (Belleview, FL), select producers from Dairy Farmers of America (Kansas City, MO), and Maryland-Virginia Milk Producers Cooperative (Reston, VA) for partial funding to support this research. Appreciation is extended to Willis Marchant

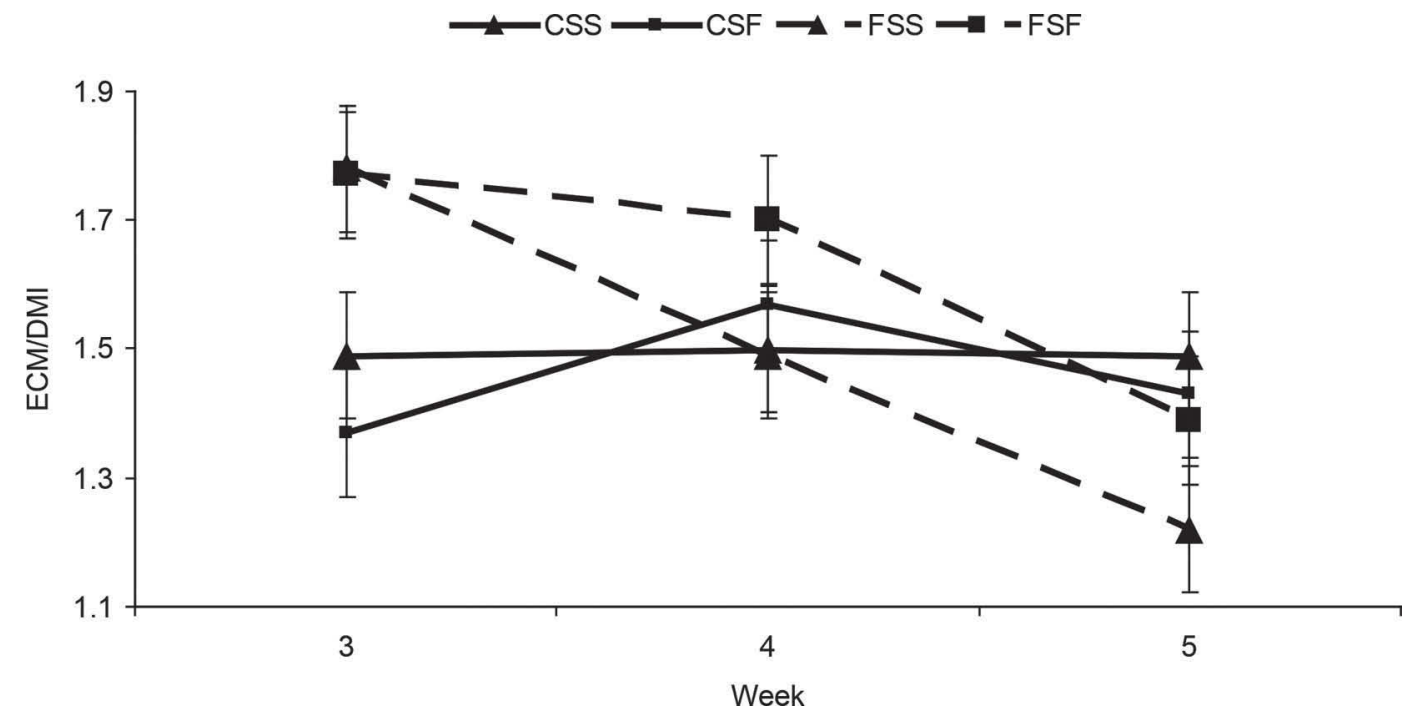

Figure 3. Interaction of treatment and week on milk production efficiency (ECM/DMI; $P<0.0001)$ of cows fed diets based on corn $(\mathrm{CS})$ or forage sorghum (FS) silage harvested in the summer $(\mathrm{S})$ or fall $(\mathrm{F})$. 


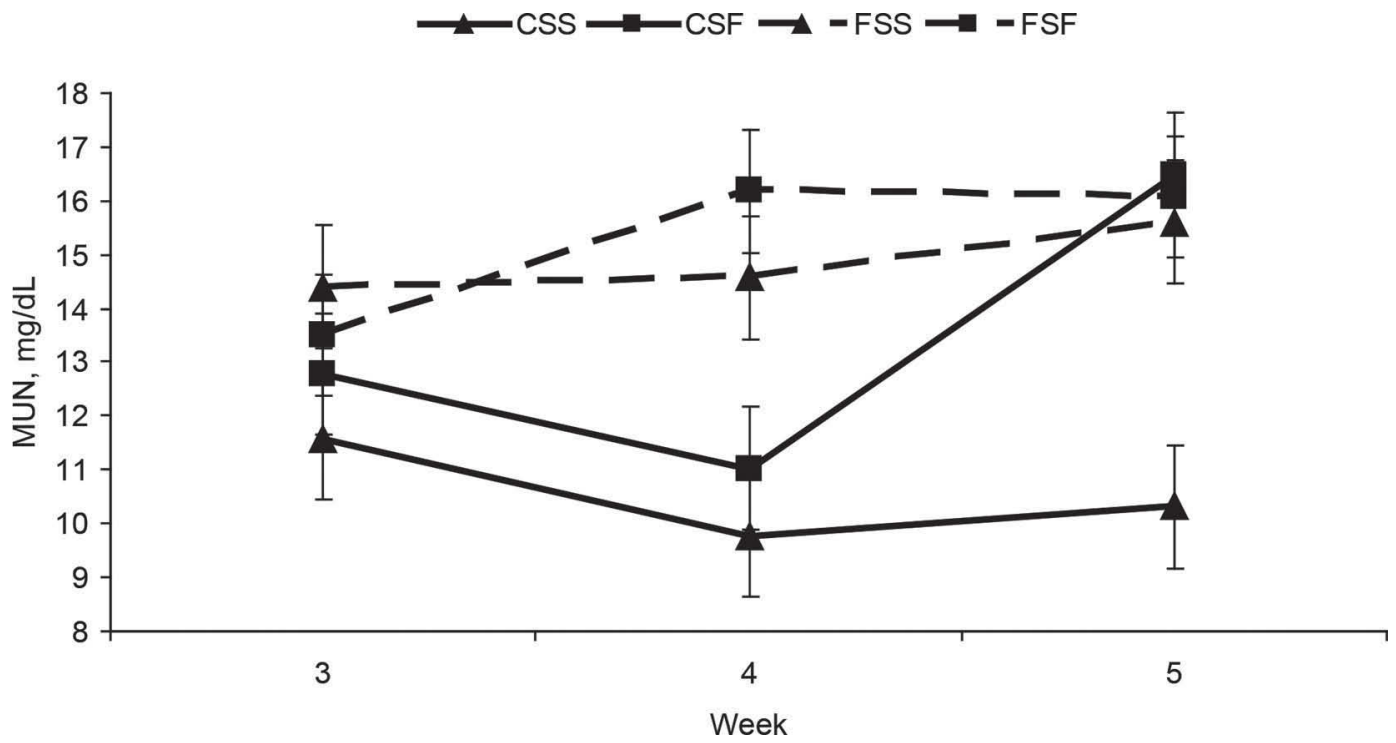

Figure 4. Interaction of treatment and week on MUN $(P=0.02)$ of cows fed diets based on corn (CS) or forage sorghum (FS) silage harvested in the summer $(\mathrm{S})$ or fall $(\mathrm{F})$.

and the farm crew (University of Georgia, Tifton) for producing and ensiling the forage used for this trial and the staff at the Dairy Research Center (Tifton, GA) for feeding, sample collection, and animal care.

\section{REFERENCES}

AOAC International. 2000. Official Methods of Analysis. 17th ed AOAC International, Gaithersburg, MD.

Aydin, G., R. J. Grant, and J. O'Rear. 1999. Brown midrib sorghum in diets for lactating dairy cows. J. Dairy Sci. 82:2127-2135.

Barlow, J. S., J. K. Bernard, and N. A. Mullis. 2012. Production response to corn silage produced from normal, brown midrib, or waxy corn hybrids. J. Dairy Sci. 95:4550-4555.

Baumgard, L. H., J. B. Wheelock, S. R. Sanders, C. E. Moore, H. B. Green, M. R. Waldron, and R. P. Rhoads. 2011. Postabsorptive carbohydrate adaptations to heat stress and monensin supplementation in lactating Holstein cows. J. Dairy Sci. 94:5620-5633.

Contreras-Govea, F., M. A. Marsalis, L. M. Lauriault, and B. W. Bean. 2010. Forage sorghum nutritive value: A review. Forage Grazinglands http://dx.doi.org/10.1094/FG-2010-0125-01-RV.

Dubois, M., K. A. Giles, J. K. Hamilton, P. A. Rebers, and F. Smith. 1956. Colorimetric method for determination of sugars and related substrates. Anal. Chem. 28:350.

Goering, H. K., and P. J. Van Soest. 1970. Forage Fiber Analyses (Apparatus, Reagents, Procedures, and Some Applications). Agric. Handbook 379. ARS-USDA, Washington, DC.

Grant, R. J., S. G. Haddan, K. J. Moore, and J. F. Pedersen. 1995. Brown midrib sorghum silage for midlactation dairy cows. J. Dairy Sci. 78:1970-1980.

Hall, M. B. 2009. Analysis of starch, including maltooligosaccharides, in animal feeds: A comparison of methods and a recommended method for AOCB collaborative study. J. AOAC Int. 92:42-49.

Littell, R. C., P. R. Henry, and C. A. Ammerman. 1998. Statistical analysis of repeated measures data using SAS procedures. J. Anim. Sci. 76:1216-1231.

Miron, J., E. Zuckerman, G. Adin, R. Solomon, E. Shoshani, M. Nikbachat, E. Yosef, A. Zenou, Z. Weinberg, Y. Chen, I. Halachmi, and D. Ben-Ghedalia. 2007. Comparison of two forage sorghum varieties with corn and the effect of feeding their silage on eating behavior and lactation performance of dairy cows. Anim. Feed Sci. Technol. 139:23-29.

Nichols, S. W., M. A. Frotschel, H. E. Amos, and L. O. Ely. 1998. Effects of fiber from tropical corn and forage sorghum silage on intake, digestion, and performance of lactating dairy cows. J. Dairy Sci. 81:2383-2393.

NRC. 2001. Nutrient Requirements of Dairy Cattle. 7th rev. ed. National Academies Press, Washington, DC.

Oba, M., and M. S. Allen. 1999. Evaluation of the importance of the digestibility of neutral detergent fiber from forage: effects on dry matter intake and milk yield of dairy cows. J. Dairy Sci. 82:589596.

Oliver, A. L., R. J. Grant, J. F. Pedersen, and J. O'Rear. 2004. Comparison of brown midrib- 6 and -18 forage sorghum with conventional sorghum and corn silage in diets of lactating dairy cows. J. Dairy Sci. 87:637-644.

SAS Institute. 2008. SAS Enterprise Guide Ver. 4.2. SAS Institute Inc., Cary, NC.

Shaver, R. D. 2010. Using high quality forages to optimize production. Western Canada Dairy Sem. Adv. Dairy Tech. 22:13-22.

Tedeschi, L. O.. W. Chalupa, E. Janczewski, D. G. Fox, C. Sniffen, R. Munson, P. J. Kononoff, and R. Boston. 2008. Evaluation and application of the CPM dairy nutrition model. J. Agric. Sci. 146:171-182.

Tylutki, T. P., D. G. Fox, V. M. Durbal, L. O. Tedeschi, J. B. Russell, M. E. Van Amburgh, T. R. Overton, L. E. Chase, and A. N. Pell. 2008. Cornell Net Carbohydrate and Protein System: A model for precision feeding of dairy cattle. Anim. Feed Sci. Technol. 143:174-202.

Van Soest, P. J., J. B. Robertson, and B. A. Lewis. 1991. Methods for dietary fiber, neutral detergent fiber, and nonstarch polysaccharides in relation to animal nutrition. J. Dairy Sci. 74:3583-3597.

Wildman, E. E., G. M. Jones, P. E. Wagner, R. L. Boman, H. F. Troutt Jr., and T. N. Lesch. 1982. A dairy cow body condition scoring system and its relationship to selected production characteristics. J. Dairy Sci. 65:495-501.

Yosef, E., A. Carmi, M. Nikbachat, A. Zenou, N. Umiel, and J. Miron. 2009. Characteristics of tall versus short-type varieties of forage sorghum grown under two irrigation levels, for summer and subsequent fall harvests, and digestibility by sheep of their silages. Anim. Feed Sci. Technol. 152:1-11. 